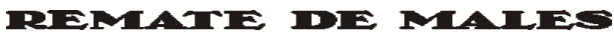

Campinas-SP, v. 38, n. 1, pp. 370-397, jan./jun. 2018

\title{
BORgES LEITOR DE DANTE
}

\author{
Heloísa Abreu de Lima ${ }^{1}$
}

Resumo: Um dos aspectos mais comumente sublinhados nos Nueve ensayos dantescos é o seu desvio do que seria a impostação predominante na prática da crítica literária - o que é frequentemente traduzido em termos de uma oposição entre Borges e a crítica dantesca. Entretanto, embora Borges de fato se afaste do tom geral dos estudos dantescos, tal polarização, cujos termos parecem indevidamente simplificados, corre o risco de permanecer à margem do verdadeiro problema presente nas suas leituras sobre a Commedia. Não obstante as formulações de Borges possam parecer respostas de um leitor inocente diante de uma obra que guarda infinitas complexidades, a verdade é que elas encobrem uma trama de expedientes de leitura - muitas vezes contraditórios entre si -, que dificilmente poderiam ser caracterizados como "inocentes". A chave de leitura de Borges, que busca frequentemente encontrar falhas e incoerências em um dos textos clássicos por excelência, pode ser vista como a maneira pela qual o autor se confronta com as chamadas "leituras totalizantes", às quais as obras canônicas são constantemente submetidas. Por isso, sua atitude não deixa de ser crítica: como bem observou Italo Calvino, os Ensayos dantescos são uma recriação de elementos do poema, marcando, assim, o posicionamento de Borges diante da tradição. Isso posto, a proposta deste estudo é reconhecer, sempre mantendo contato direto com o texto de Dante, os diferentes procedimentos de leitura de Borges e as suas implicações críticas ao longo dos Nueve ensayos dantescos.

Palavras-chave: Nueve ensayos dantescos; Jorge Luis Borges; Dante Alighieri.

Certamente, um dos traços mais singulares dos Nueve ensayos dantescos é o seu claro desvio do tom tradicional da crítica literária. Tal impostação não deixou de ser notada por estudiosos da obra de Borges, embora frequentemente traduzida em termos de uma suposta oposição entre Borges e "a crítica dantesca", em que o escritor argentino assume o lugar do chamado "leitor inocente". Tal ideia se apresenta, por exemplo,

1 Mestranda em Teoria e História Literária pela Universidade Estadual de Campinas (Unicamp): heloisa.abreu96@gmail.com. 
no seguinte trecho de Alberto Giordano (2005c, pp. 57-58), que opõe ao "leitor inocente" de Borges o "leitor advertido", determinado pelas imposições da "crítica dantesca":

El lector "advertido", el que ya sabe, antes de que la lectura ocurra, qué debe leer, se aplica al desciframiento de los diferentes sentidos que entraña la estructura alegórica del poema. Su consigna es acabar con la ambigüedad: enumerar y nombrar sin faltas los sentidos. Otro es el ejercicio del lector inocente, del que se aventura en su experiência de la Comedia. ${ }^{2}$

À primeira vista, esta parece ser, de fato, a leitura mais pertinente; e alguns momentos dos Ensayos dantescos poderiam corroborá-la. Por exemplo, é quase inevitável não pensar em uma "leitura inocente" quando, tratando da Commedia, Borges (1998a, p. 149) afirma: "Yo sospecho que Dante edificó el mejor libro que la literatura ha alcanzado para intercalar algunos encuentros con la irrecuperable Beatriz" ${ }^{3}$ Realmente, transformar um poema do porte da Commedia em uma das mais singelas histórias de amor pode não parecer senão obra de uma leitura inocente, alheia às tantas complexidades que o livro encerra.

Entretanto, o confronto com os diferentes comportamentos presentes nos Ensayos dantescos - sempre com atenção ao próprio texto da Commedia - cria problemas que dificilmente poderiam ser resolvidos em termos de uma dualidade entre Borges e a "crítica dantesca" dualidade que não é homogênea em nenhum de seus extremos. Em primeiro lugar, deve-se precisar que a relação de Borges com a tradição de estudos sobre a Commedia não pode ser resolvida em termos simples, pois, se bem que muitas vezes o autor argentino claramente se oponha a formulações críticas a respeito da Commedia, ele não deixa de tomar diversos comentadores como aparato e ponto de partida para suas

2 “O leitor 'avisado', aquele que, antes da leitura, já sabe o que deve ler, aplica-se ao deciframento dos diferentes sentidos que a estrutura alegórica do poema compreende. Sua máxima é acabar com a ambiguidade: enumerar e nomear os sentidos. Outro é o exercício do leitor inocente, que se aventura na sua experiência da Comédia." As traduções das citações são nossas, salvo quando indicamos a referência.

3 "Tenho a impressão de que Dante edificou o melhor livro produzido pela literatura para intercalar alguns encontros com a irrecuperável Beatriz." (BORGES, 2011, p. 58). Todos os trechos dos Nueve ensayos dantescos aqui transcritos são da edição: Borges (1998a) e as respectivas traduções: Borges (2011). 


\section{leituras, manifestando conhecimento abrangente acerca da tradição de comentários da Commedia: ${ }^{4}$}

Leí muchas veces la Comedia, en distintas ediciones, y pude gozar de los comentarios. De todas ellas, dos me reservo particularmente: la de Momigliano y la de Grabher. Recuerdo también la de Hugo Steiner.

Leía todas las ediciones que encontraba y me distraía con los distintos comentarios, las distintas interpretaciones de esa obra múltiple. Comprobé que en las ediciones más antiguas predomina el comentario teológico; en las del siglo diecinueve, el histórico, y actualmente el estético, que nos hace notar la acentuación de cada verso, una de las máximas virtudes de Dante. (BORGES, 1993, p. 13) $)^{5}$

Tal afirmação se encontra na conferência "La divina comedia", presente no volume Siete noches; nela, estão diversas constantes dos Ensayos dantescos - o que, acredito, autoriza uma leitura dos ensaios à luz da conferência.

Se, nessa mesma conferência, Borges insiste sobre a necessidade de uma "leitura ingênua" da Commedia ${ }^{6}$ - enquanto dever de todos os

\footnotetext{
4 "Muy pocos textos de la tradición occidental han sido leídos con un carácter tan 'deliberado y fatal' como la Commedia de Dante Alighieri. [...] Dentro de esta tradición crítica dantesca, la aproximación borgeana resulta altamente heterodoxa. En primer lugar, Borges conoce bien la tendencia a considerar la Commedia como una unidad perfecta. En sus textos hay frecuentes comentarios a varios aparatos críticos: Buti, Tommaseo, Steiner, Pietro di Dante, Boccaccio, Vitali, Torraca son nombres de la tradición de comentarios de la Commedia que están presentes en las páginas de sus Nueve ensayos dantescos, publicados en 1982." [Poucos textos da tradição ocidental foram lidos em modo tão 'deliberado e fatal' como a Comédia de Dante Alighieri. [...] Dentro dessa tradição crítica dantesca, a aproximação borgeana resulta altamente heterodoxa. Em primeiro lugar, Borges conhece bem a tendência a considerar a Comédia como uma unidade perfeita. Em seus textos há frequentes comentários a vários aparatos críticos: Buti, Tommaseo, Steiner, Pietro di Dante, Boccaccio, Vitali, Torraca são nomes da tradição de comentários da Comédia que estão presentes nas páginas de seus Nove ensaios dantescos, publicados em 1982.] (VALENCIA, 2015, p. 940).

5 "Li muitas vezes a Comédia, em diversas edições, e pude desfrutar dos comentários. De todas eles, dois me reservo particularmente: a de Momigliano e a de Grabher. Recordo também a de Hgo Steiner. Lia todas as edições que encontrava e me distraía com os diferentes comentários, as diferentes interpretações dessa obra multíplice. Verifiquei que na edições mais antigas predomina o comentário teológico; nas do século XIX, o comentário histórico, e atualmente o comentário estético, que nos faz notar a configuração e cada verso, uma das maiores virtudes de Dante."

6 "Quiero solamente insistir sobre el hecho de que nadie tiene derecho a privarse de esa felicidad, la Comedia, de leerla de un modo ingenuo. Después vendrán los comentarios, el deseo de saber qué significa cada alusión mitológica, ver cómo Dante tomó un gran verso de Virgilio y acaso lo mejoró traduciéndolo. Al principio debemos leer el libro con fe de niño, abandonarnos a él; después nos acompañará hasta el fin. A mí me ha
} 
leitores -, isso não significa que essa seja necessariamente a leitura proposta em seus Nueve ensayos dantescos, em cujo "Prólogo" ele afirma que a felicidade de ler Dante com inocência "nos está vedada" (BORGES, 1998a, p. 83). É difícil reconhecer uma leitura inocente em um ensaio como "Dante y los visionarios anglosajones", em que o autor, com sua rara erudição, traça paralelos entre Dante e Beda, de modo a fazer deste um precursor daquele. O mesmo ocorre com "Purgatorio', I, 13”, o qual põe um verso da Commedia ao lado de versos de diferentes poetas, e com "El Simurgh y el Águila", dedicado a comparar duas "figuras memoráveis" - uma da literatura ocidental, outra da literatura oriental (BORGES, 1998a, p. 134). Esses são apenas alguns sinais mais visíveis não de mera erudição, mas de uma consciência de leitura que, longe de qualquer inocência, está no controle dos resultados de cada uma de suas interpretações.

A verdade é que a leitura de Borges - e atenho-me aqui somente ao que concerne à Commedia - é menos inocente do que a princípio se pode supor: os Ensayos dantescos encerram uma trama de manipulações, leituras parciais, arbitrariedades e até mesmo contradições internas, que são tão deliberadas quanto veladas dentro de suas formulações aparentemente tão simples. Isso pode ser avaliado como resultado da manifesta oposição de Borges às chamadas "leituras totalizantes", que tomam o texto literário como construção perfeita, como estrutura orgânica completamente coerente e causal na relação entre os seus elementos; e tanto mais contundente pode ser essa leitura quanto mais "canônica” é a obra considerada.

Escusado dizer que a Commedia, enquanto um dos clássicos por excelência, foi um dos textos mais submetidos a tal modo de leitura, ao qual Borges, como sublinha Valência (2015, p. 945), opõe-se nas principais discussões dos seus Ensayos dantescos: "En primer lugar, Borges es un fuerte crítico de toda lectura totalizante, no sólo de la

acompañado durante tantos años, y sé que apenas lo abra mañana encontraré cosas que no he encontrado hasta ahora." [Quero somente insistir sobre o fato de que ninguém tem o direito de se privar dessa felicidade, de ler a Comedia de um modo ingênuo. Depois virão os comentários, o desejo de saber o que significa cada alusão mitológica, ver como Dante tomou um grande verso de Virgílio e talvez o tenha melhorado, traduzindo-o. No início, devemos ler o libro com fé infantil, devemos nos abandonar a ele; depois ele nos acompanhará até o fim. A mim, ele acompanhou durante muitos anos, e sei que assim que eu o abrir amanhã, encontrarei coisas que não encontrei até agora.] (BORGES, 1993, pp. 31-32). 
literatura. La metafísica occidental también ha hecho una 'lectura' de la realidad que pretende encontrar las leyes estrictas e inmutables que rigen al mundo". ${ }^{7}$ Por outro lado, pode-se igualmente concordar em dizer que uma das fontes da admiração de Borges pela Commedia está nos inúmeros sentidos que perpassam o poema, os quais, contra qualquer tentativa de resolução definitiva, ainda hoje desafiam os intérpretes e comentadores:

No es extraño que la condición de texto múltiple de la Divina comedia sea uno de los elementos que con mayor fuerza atraiga la atención del maestro argentino; ya en Discusión nos dice que "el frenesí de llegar a una conclusión es la más funesta y estéril de las manías" [...]. Manía contra la que el genio borgeano se rebela constantemente. (ARDAVÍN, 1996, p. 83) ${ }^{8}$

Ideia cara a Borges, a Commedia é um texto aberto a inúmeras leituras; a isso se une, ademais, a concepção medieval dos diversos níveis de leitura de um mesmo texto - da qual o próprio Dante era adepto e da qual Borges (1993, p. 10) se apropria para ler o texto daquele:

La ideia de un texto capaz de múltiples lecturas es característica de la Edad Media, esa Edad Media tan calumniada y compleja que nos ha dado la arquitectura gótica, las sagas de Islandia y la filosofía escolástica en la que todo está discutido. Que nos dio, sobre todo, la Comedia, que seguimos leyendo y que nos sigue asombrando, que durará más allá de nuestra vida, mucho más allá de nuestras vigilias y que será enriquecida por cada generación de lectores. ${ }^{9}$

As múltiplas possibilidades de interpretação fazem da Commedia o texto ideal para Borges realizar a sua leitura que, antes de se apegar ao aspecto grandioso ou sublime da obra, quer focalizar alguns de seus detalhes, destacando-os da sua totalidade e, portanto, rompendo com uma leitura totalizante:

7 "Em primeiro lugar, Borges é um forte crítico de toda leitura totalizante, não só com respeito à literatura. A metafísica ocidental também fez uma 'leitura' da realidade que pretende encontrar as leis estritas e imutáveis que regem o mundo."

8 "Não é estranho que a condição de texto multíplice da Divina comédia seja um dos elementos que com maior força atraia a atenção do mestre argentino; já em Discusión ele nos diz que 'o frenesi de chegar a uma conclusão é a mais funesta e estéril das manias'. Mania contra a qual o gênio borgeano se rebela constantemente."

9 "A ideia de um texto capaz de múltiplas leituras é característica da Idade Média, essa Idade Média tão caluniada e complexa que nos deu a arquitetura gótica, as sagas da Islândia e a filosofia escolástica em que tudo é discutido. Que nos deu, sobretudo, a Comédia, que continuamos a ler e que continua a nos surpreender, que durará além de nossas vigílias e que será enriquecida por cada geração de leitores.” 
He fantaseado una obra mágica, una lámina que también fuera un microcosmo; el poema de Dante es esa lámina de ámbito universal. Creo, sin embargo, que si pudiéramos leerlo con inocencia (pero esa felicidad nos está vedada), lo universal no sería lo primero que notaríamos y mucho menos lo sublime o grandioso. Mucho antes notaríamos, creo, otros caracteres menos abrumadores y harto más deleitables; en primer término, quizá, el que destacan los dantistas ingleses: la variada y afortunada invención de rasgos precisos. (BORGES, 1998a, pp. 83-84) ${ }^{10}$

Não poucas vezes os estudiosos notaram o valor que Borges confere, nos Ensayos dantescos, a elementos particulares do poema de Dante (como um verso, uma fala, um gesto), capazes - e nisso é costume haver concordância entre os críticos - de definir um personagem em toda a sua profundidade, mediante uma poderosa concisão:

Tento di sintetizzare le ragioni del fascino, acuto e duraturo, fervido e generoso di suggestioni, di Dante su Borges. Innanzitutto, la felicità della parola nel definire un dettaglio, così che la visione fantastica diventa reale, e lo stesso vale non solo per i dettagli che descrivono una situazione di gesti e di corpi in movimento, ma anche per l'espressività di particolari sfumature psicologiche: Dante è descrittore mirabile sia dell'oggetto sia del soggetto, la sua visione diventa la nostra perché ce la racconta, e così anche l'astronomia tolemaica e la teologia cristiana diventano mezzi per mostrare al lettore i tre regni dell'Aldilà. Per questo il primo modo di approccio alla Commedia è per

10 "Imaginei uma obra mágica, uma estampa que também fosse um microcosmo; o poema de Dante é essa estampa de âmbito universal. Penso, contudo, que se pudéssemos lê-lo com inocência (mas essa felicidade está fora de nosso alcance), o universal não seria a primeira coisa que perceberíamos, muito menos o sublime ou o grandioso. Muito antes perceberíamos, penso, outras características menos opressivas e muito mais deleitáveis; antes de mais nada, talvez, a destacada pelos dantistas ingleses: a variada e bem-sucedida invenção de traços precisos." (BORGES, 2011, p. 9). Isso autoriza Giordano (2005c, p. 56) a afirmar: "Es otro modo de decir que despojando a la Comedia de su grandiosidad y su sublimidad y convirtiéndola en una 'antología casual' [...] de circunstancias felices o conmovedoras, siempre inauditas, Borges devuelve al poema de Dante su condición de clásico, es decir, de texto 'capaz de casi inagotables repeticiones, versiones, perversiones"' [É outro modo de dizer que, despojando a Comédia de sua grandiosidade e de sua sublimidade e tornando-a uma "antologia casual" [...] de circunstâncias felizes ou comovedoras, sempre inauditas, Borges restitui ao poema sua condição de clássico, isto é, de texto “capaz de quase inesgotáveis repetições, versões, perversões”]. 
Borges attenersi al racconto, così come in teatro e al cinema ci abbandoniamo alla finzione. (LAGORIO, 2003, pp. 27-28) ${ }^{11} 12$

\section{Borges (1993, pp. 14-15) tem nos detalhes ${ }^{13}$ da Commedia uma fonte de deleite, à qual ele dá especial destaque, fazendo de alguns deles}

11 "Tento sintetizar as razões do fascínio, agudo e duradouro, férvido e generoso de sugestões, de Dante sobre Borges. Em primeiro lugar, a felicidade da palavra ao definir um detalhe de modo que a visão fantástica se torna real, e o mesmo vale não só para os detalhes que descrevem uma situação de gestos e de corpos em movimento, mas também para a expressividade de particulares esfumaturas psicológicas: Dante descreve admiravelmente seja o objeto seja o sujeito, a sua visão se torna nossa porque ele a narra para nós, e assim também a astronomia ptolemaica e a teologia cristã se tornam meios para mostrar ao leitor os três reinos do Além. Por isso o primeiro modo de aproximação à Comédia é para Borges ater-se à história, assim como no teatro e no cinema nos abandonamos à ficção."

12 Cf. também: "spesso nella rappresentazione dei personaggi non è tanto la verità storica - sebbene dato fondamentale - ciò che prevale, quanto la verità psicologica, ovvero come riuscire a esprimere attraverso un gesto, una parola, uno sguardo, l'intera storia terrena e spirituale di un essere umano" [frequentemente na representação dos personagens não é tanto a verdade histórica - ainda que dado fundamental - aquilo que prevalece, quanto à verdade psicológica, vale dizer, como conseguir exprimir através de um gesto, uma palavra, um olhar, a inteira história terrena e espiritual de um ser humano.] (FRESKO, 2003, pp. 33-34). E, para além dos Ensayos dantescos, tal técnica de composição foi fundamental para a produção ficcional de Borges: "Una novela contemporánea requiere quinientas o seiscientas páginas para hacernos conocer a alguien, si es que lo conocemos. A Dante le basta un solo momento. En ese momento el personaje está definido para siempre. Dante busca ese momento central inconscientemente. Yo he querido hacer lo mismo en muchos cuentos y he sido admirado por ese hallazgo, que es el hallazgo de Dante en la Edad Media, el de presentar un momento como cifra de una vida. En Dante tenemos esos personajes, cuya vida puede ser la de algunos tercetos y sin embargo esa vida es eterna. Viven en una palabra, en un acto, no se precisa más; son parte de un canto, pero esa parte es eterna. Siguen viviendo y renovándose en la memoria y en la imaginación de los hombres" [Um romance contemporâneo precisa de quinhentas ou seiscentas páginas para nos fazer conhecer alguém, se é que o conhecemos. A Dante, basta um só momento. Nesse momento, o personagem é definido para sempre. Dante busca esse momento central inconscientemente. Eu quis fazer o mesmo em muitos contos e fui admirado por esse achado - que é o achado de Dante na Idade Média - de apresentar um momento como chave de uma vida. Em Dante temos esses personagens cuja vida pode ser de apenas alguns tercetos e, não obstante, essa vida é eterna. Vivem em uma palavra, em um ato, não se especifica mais; são parte de um canto, mas essa parte é eterna. Continuam vivendo e renovando-se na memória e na imaginação dos homens] (BORGES, 1993, p. 20).

13 Emprega-se aqui a terminologia de Alberto Giordano, que destacou com bastante atenção tal característica no ensaísmo de Borges: "Borges nos enseñó a leer la totalidad desde el detalle. Desde y no en: el detalle que atrae la atención del lector y lo hace olvidar por un momento la totalidad de la obra vale por ésta, no porque la represente, sino porque instaura un nuevo punto de vista para pensarla" [Borges nos ensinou a ler a totalidade a partir do detalhe. A partir do detalhe e não no: o detalhe que atrai a atenção do leitor e o faz esquecer por um momento a totalidade da obra, que vale por esta, não porque a represente, mas porque instaura um novo ponto de vista para pensá-la] (GIORDANO, 2005a, p. 9). 
temas de seus Ensayos dantescos e oferecendo um aspecto, ao que lhe parece, frequentemente esquecido da obra: "Quiero recordar otro rasgo: la delicadeza de Dante. Siempre pensamos en el sombrío y sentencioso poema florentino y olvidamos que la obra está llena de delicias, de deleites, de ternuras. Esas ternuras son parte de la trama de la obra”. ${ }^{14}$

Isso é especialmente notável pelo tema de alguns dos Ensayos: o famoso e ambíguo verso de Ugolino, a metáfora presente em um verso do "Purgatorio", criando um jogo de espelhos, o último sorriso de Beatriz. Entretanto, importa aqui sublinhar o modo como Borges constrói seu discurso em torno do detalhe. O que ocorre, na verdade, é um ato de descontextualização constantemente atualizado, em que o detalhe passa a valer por toda a obra, sendo discutido, analisado e interpretado por si mesmo, sem, por outro lado, ser reduzido a elemento representativo de uma totalidade:

Borges no se interesa por la articulación de las grandes secuencias simbólicas [...], ni por las intrincadas combinaciones de temas y motivos, ni por los abigarrados conjuntos de personajes. En todo caso, si los tiene en cuenta, es sólo como contextos de aparición, de emergencia de un detalle, pero no para someter el detalle a la ley del contexto (que prescribe reducir lo singular a lo particular, lo curioso a lo representativo), sino para hacer más sensible la fuerza de irreductibilidad que anima a todo detalle, su poder de desprenderse de lo que lo condiciona. (GIORDANO, 2005c, p. 55) ${ }^{15}$

Não é preciso ir muito longe para perceber os possíveis efeitos disso: Borges não faz simplesmente uma descrição de determinado elemento do poema que o deleitou e despertou sua emoção. A partir do efeito que o detalhe tem sobre sua sensibilidade, e operando uma crescente descontextualização, o autor assume total controle sobre a leitura e recepção desse mesmo detalhe e, a partir dele, de uma situação mais ampla do poema.

14 "Quero recordar outro traço: a delicadeza de Dante. Sempre pensamos no sombrio e sentencioso poema florentino e esquecemos que a obra está cheia de delícias, de deleites, de ternuras. Essas ternuras são parte da trama da obra."

15 "Borges não se interessa pela articulação das grandes sequências simbólicas [...], nem pelas intrincadas combinações de temas e motivos, nem pelos variegados conjuntos de personagens. Em qualquer caso, se os considera, é só como contextos de aparição, de emergência de um detalhe, mas não para submeter o detalhe à lei do contexto (que manda reduzir o singular ao particular, o curioso ao representativo), mas para tornar mais sensível a força de irredutibilidade que anima todo detalhe, seu poder de se desprender do que o condiciona." 
Assim inicia Borges (1998a, p. 147) o último de seus Ensayos dantescos:

Mi propósito es comentar los versos más patéticos que la literatura ha alcanzado. Los incluye el canto XXXI del Paraíso y, aunque famosos, nadie parece haber discernido el pesar que hay en ellos, nadie los escuchó enteramente. Bien es verdad que la trágica sustancia que encierran pertenece menos a la obra que al autor de la obra, menos a Dante protagonista que a Dante redactor o inventor. ${ }^{16}$

A partir disso, faz uma breve introdução para situar os versos no poema, citando, em seguida, a terzina em questão: "Così orai; e quella, sì lontana/ come parea, sorrise e riguardommi;/ poi si tornò a l'etterna fontana" (Paradiso, ${ }^{17}$ XXXI, 91-93). ${ }^{18} \mathrm{O}$ autor cita algumas interpretações da passagem, fornecidas por diversos comentadores e estudiosos. Então diz "Reconsideremos la escena" [Reconsideremos a cena] (BORGES, 1998a, p. 150) e apresenta a sua leitura, fundamentada mais por elementos externos do que internos, como ele mesmo já havia antecipado no primeiro parágrafo: os versos são patéticos pelo sentido profundo que encerram não em relação à obra, mas em relação ao autor da obra.

Entretanto, quando se considera a "introdução" do ensaio, percebe-se que ela não é realizada de modo a fornecer elementos para a interpretação da terzina em questão, mas para evidenciar a que momento do poema ela se refere: trata-se do final da jornada de Dante, precisamente no momento da despedida de Beatriz. Logo, a terzina corresponde à despedida de Beatriz - até aqui, não se trata de interpretação, mas de um fato do poema: a interpretação só terá início com o sentido atribuído a esse fato. Assim, o que Borges cita do poema nesse ensaio não é empregado com a finalidade de contextualizar a terzina e oferecer uma interpretação mais conforme ao clima geral do canto. Trata-se do expediente descrito por Giordano: a situação dos versos conta apenas como contexto de emergência do detalhe, o qual, contudo, não se subordina ao contexto. Nesse caso, Borges (1998a, pp. 151-153) quer marcar esse momento crucial,

16 "Meu objetivo é comentar os versos mais patéticos que a literatura já produziu. Fazem parte do canto XXXI do Paraíso e, embora famosos, ninguém parece ter discernido o pesar que existe neles, ninguém os escutou por inteiro. É bem verdade que a trágica substância que eles encerram pertence menos à obra que ao autor da obra, menos a Dante protagonista que a Dante redator ou inventor." (BORGES, 2011, p. 57).

17 Todos os trechos da Commedia aqui transcritos estão de acordo com o texto estabelecido por Giorgio Petrocchi, em Dante (1966-1967), La commedia, secondo l'antica vulgata.

18 "Desta arte orei. Lá da sublime altura, /em que estava sorrindo-se encarou-me; /depois voltou-se à eterna Formosura." (ALIGUIERI, 1946). 
para motivar a sua leitura "patética", cuja verdadeira chave está fora do poema:

Retengamos un hecho incontrovertible, un solo hecho humildísimo: la escena ha sido imaginada por Dante. Para nosotros, es muy real; para él, lo fue menos. (La realidad, para él, era que primero la vida y después la muerte le habían arrebatado a Beatriz.) Ausente para siempre de Beatriz, solo y quizá humillado, imaginó la escena para imaginar que estaba con ella. Desdichadamente para él, felizmente para los siglos que lo leerían, la conciencia de que el encuentro era imaginario deformó la visión. De ahí las circunstancias atroces, tanto más infernales, claro está, por ocurrir en el empíreo: la desaparición de Beatriz, el anciano que toma su lugar, su brusca elevación a la Rosa, la fugacidad de la sonrisa y de la mirada, el desvío eterno del rostro. En las palabras se trasluce el horror: come parea se refiere a lontana pero contamina a sorrise [...]. También eterna parece contaminar a si tornò. ${ }^{19}$

Desse modo, Borges lê a terzina segundo o amor infeliz de Dante por Beatriz (como registrado na Vita nuova); amor cuja infelicidade ele não pôde mudar em seu poema, deixando transparecer nesses versos todo o horror de sua situação real, isto é, sua eterna separação de Beatriz.

A princípio, quando se lê tal conclusão - que é, de fato, muito envolvente no sentido profundo que atribui aos versos -, chega-se mesmo a acreditar que essa seja a substância deles. Entretanto, quando se lê o canto em que eles estão presentes, nada se faz mais estranho à sua entonação geral, ao fato de Dante estar prestes a viver a experiência fundamental de seu poema (a visão de Deus), ao seu destaque do plano humano com extrema liberdade expressiva - nada se faz mais estranho a isso do que as "circunstâncias atrozes" e "infernais", do que a ideia de "horror". A admiração com a qual Dante olha para São Bernardo está longe de ser a "circunstância atroz" em que o ancião ocupa o lugar de Beatriz:

19 "Consideremos um fato indiscutível, um único fato humilíssimo: a cena foi imaginada por Dante. Para nós, ela é muito real; para ele, foi menos. (A realidade, para ele, era que primeiro a vida e depois a morte lhe haviam arrebatado Beatriz.) Ausente para sempre Beatriz, sozinho e quem sabe humilhado, imaginou a cena para imaginar que estava com ela. Desgraçadamente para ele, felizmente para os séculos que o leriam, a consciência de que o encontro imaginário deformou a visão. Daí as circunstâncias atrozes, tanto mais infernais, obviamente, por transcorrerem no empíreo: o desaparecimento de Beatriz, o ancião que ocupa seu lugar, a brusca elevação de Beatriz à Rosa, a fugacidade do sorriso e do olhar, o desvio eterno do rosto. Nas palavras transparece o horror: come parea se refere a lontana, mas contamina sorrise [...]. Eterna também parece contaminar si tornò." (BORGES, 2011, pp. 60-61). 
Qual è colui che forse di Croazia

viene a veder la Veronica nostra,

che per l'antica fame non sen sazia,

ma dice nel pensier, fin che si mostra:

"Segnor mio Iesù Cristo, Dio verace,

or fu sì fatta la sembianza vostra?";

tal era io mirando la vivace

carità di colui che 'n questo mondo,

contemplando, gustò di quella pace.

(Paradiso, XXXI, 103-111) ${ }^{20}$

O início do ensaio cria a falsa impressão de contextualização da terzina, mas não é essa a sua intenção. Borges, ao situar os versos, sublinha o fato de eles corresponderem à despedida de Beatriz; a partir disso, ele realiza uma leitura baseada não em elementos do poema, mas em acontecimentos da vida de Dante (ao menos tal como delineada na Vita nuova); e essa leitura resulta muito mais patética do que no poema. ${ }^{21}$ Borges, ao desconsiderar elementos do canto em questão, descontextualiza a terzina interpretada, de modo a poder realizar com mais liberdade a sua conexão com o amor "real" de Dante, e conduzir, assim, ao conteúdo profundo e trágico que quer atribuir aos versos. E sua descrição é tão envolvente que logra convencer o leitor que esteja em contato menos direto com o contexto do poema.

É nesse sentido que se pode dizer que Borges realiza uma leitura "parcial" da Commedia, manipulando estrategicamente alguns elementos,

20 "Como quem da Croácia se destina /a ver Santo Sudário em romaria, /por fama antiga da feição divina; /devoto a contemplar se não sacia, /dizendo em si: 'ó Jesus! meu Deus piedoso! /Tal o semblante vosso parecia!' /Assim notei o afeito caridoso /daquele, que em seus êxtases no mundo /a paz celeste prelibou ditoso." (ALIGHIERI, 1946).

21 "The pathos that has left Borges so clearly affected - and that in some ways in Borges's recounting is far more passionate than we are used to reading in Dante himself - is not only that Dante's mortal, earthly, 'real' love was unrequited and tragic, but that even in fiction, a monumental fiction constructed precisely so that he could meet the vanished Beatrice once again, Dante could not fully falsify matters, could not be glaringly untrue to the earthly truth that had scarred and shaped him." [O pathos que deixou Borges tão claramente impressionado - e que, de certo modo, é muito mais apaixonado na sua narração do que nós estamos acostumados a ler no próprio Dante - é não só que o amor mortal, terreno, "real", de Dante não era correspondido e era trágico, mas que até na ficção, uma monumental ficção construída precisamente pare que ele pudesse encontrar a ausente Beatriz mais uma vez, Dante não conseguiu alterar completamente os acontecimentos, não conseguiu ser tão clamorosamente infiel à verdade terrena que o marcara e moldara.] (MENOCAL, 1991, p. 132). 
ignorando deliberadamente outros, de modo a criar uma leitura fragmentada e tendenciosa, ou, vale dizer, "contra-canônica":

en Borges también hay un impulso contra-canónico por encontrar lo "menor" en textos canónicos, precisamente a partir de un uso estratégico de los fragmentos específicos de un texto [...]. Este tipo de trabajo, basado en fragmentos discretos y en citas, muchas veces extraídas a propósito de su contexto original, define buena parte la interacción borgeana con los clásicos. (VALENCIA, 2015, p. 939) 22 $^{22}$

Essa é a leitura que caracteriza a relação de Borges com o texto clássico - relação baseada em um constante impulso de ruptura com a ideia de coerência interna. E esse é um segundo aspecto que assume a valorização que ele faz dos detalhes da Commedia: Borges, buscando romper com uma leitura totalizante, encontra no poema não só detalhes dos quais trata detidamente, mas também detalhes que se resolvem em incoerências, anomalias, ambiguidades - basicamente, detalhes que investem contra a ideia de coerência absoluta do poema: "Borges se interesa por aquellos incidentes que conspiran contra la coherencia semántica de la Comedia, por aquellos pormenores que aparecen bajo la forma de 'discordias', 'anomalías', 'ambigüedades' y 'paradojas"' (GIORDANO, 2005c, p. 6o). ${ }^{23}$ Isso é particularmente evidente no ensaio "El verdugo piadoso" (título que manifesta o gosto borgeano pelo oximoro), ${ }^{24}$ o qual gira em torno de uma "discrepância": "Dante (nadie lo ignora) pone a Francesca en el Infierno y oye con infinita compasión la historia de su culpa. ¿Cómo atenuar esa discordia, cómo justificarla? Vislumbro cuatro conjecturas posibles" (BORGES, 1998a, p. 113). ${ }^{25}$ Percebe-se que tal atenção à incoerência pode revelar em si também uma carga de irreverência diante do texto clássico. Trata-se, de certo modo,

22 “[...] em Borges também há um impulso contracanônico para encontrar o 'menor' em textos canônicos, precisamente a partir de um uso estratégico dos fragmentos específicos de um texto [...]. Esse tipo de trabalho, baseado em fragmentos discretos e em citações, muitas vezes extraídas propositalmente de seu contexto original, define boa parte da interação borgeana com os clássicos."

23 "Borges se interessa por aqueles casos que conspiram contra a coerência semântica da Comédia, por aqueles pormenores que aparecem sob a forma de 'discórdias', 'anomalias', 'ambguidades' e paradoxos."

24 Cf. Giordano, 2005c, pp. 6o-62.

25 "Dante (ninguém ignora) põe Francesca no Inferno e ouve com infinita compaixão a história de sua culpa. Como atenuar essa discrepância? Como justificá-la? Vislumbro quatro conjeturas possíveis." (BORGES, 2011, p. 34). 
de uma dessacralização do texto canônico, quase imposto ao leitor como uma estrutura grandiosa e perfeita:

lo que vemos en su lectura no es una voluntad de unificar el texto, sino la deliberada selección de unos pocos elementos, trabajados de forma estratégica, muchas veces descontextualizados, para obtener de ellos lecturas novedosas, inesperadas e irreverentes: lo que Sarlo llama aspectos "menores" en literaturas y textos "mayores". (VALENCIA, 2015, p. 946) ${ }^{26}$

É o que ocorre, por exemplo, em "El noble castillo del canto cuarto", em que o autor atribui o silêncio dos personagens desse círculo a uma possível falta de domínio da técnica que Dante só descobrirá no canto seguinte: "En el canto V, Dante hizo hablar inmortalmente a Francesca da Rimini; en el anterior, qué palabras no habría dado a Aristóteles, a Heráclito o a Orfeo, si ya hubiera pensado en ese artificio. Deliberado o no, su silencio agrava al horror y conviene a la escena" (BORGES, 1998a, p. 97$).^{27}$

Entretanto, para retornar à questão de Francesca, importa também o modo como Borges resolve (ou não resolve) o problema proposto. Desenvolvendo as quatro conjeturas, o autor conclui que somente a última - a qual não resolve o problema, mas apenas o formula de modo a torná-lo extremo - é a verdadeira: "La cuarta conjetura, como se ve, no desata el problema. Se limita a plantearlo, de modo enérgico. Las otras conjeturas eran lógicas; esta, que no lo es, me parece verdadera"

26 "[...] o que vemos em sua leitura não é uma vontade de unificar o texto, mas sim a deliberada seleção de uns poucos elementos, trabalhados de forma estratégica, muitas vezes descontextualizados, para obter deles leituras originais, inesperadas e irreverentes: o que Sarlo chama aspectos 'menores' em literaturas e textos 'maiores.'

27 "No canto V, Dante fez falar imortalmente Francesca da Rimini; no anterior, que palavras não teria dado a Aristóteles, Heráclito ou Orfeu se já tivesse pensado nesse artifício! Deliberado ou não, o silêncio dos três agrava o horror e convém à cena." (BORGES, 2011, p. 20). A mesma ideia se faz presente em "La divina comedia", em uma relação estabelecida entre os cantos IV e V do Inferno: "Al llegar a ese círculo en el que están penando los lujuriosos, hay grandes nombres ilustres. Digo 'grandes nombres' porque Dante, cuando empezó a escribir el canto, no había llegado aún a la perfección de su arte, al hecho de hacer que los personajes fueran algo más que sus nombres. Sin embargo esto le sirvió para describir al nobile castello" [Ao chegar a este círculo em que estão penando os luxuriosos, encontra grandes nomes ilustres. Digo "grandes nomes" porque Dante, quando começou a escrever o canto, não havia chegado ainda à perfeição de sua arte, ao feito de tornar seus personagens algo mais do que seus nomes. Não obstante, isso bastou para descrever o nobile castel.] (BORGES, 1993, p. 21). 
(BORGES, 1998a, p. 117). ${ }^{28}$ Tem-se aqui o gosto do autor por permanecer na incerteza e por extremá-la tanto quanto possível, como observou Giordano (2005c, p. 59):

La incertidumbre es ambigüedad, pero irreductible: ambigüedad que no quiere ser reducida, tensión que no quiere apaciguarse. Por eso la incertidumbre es un valor para la ética borgiana, para la ética del ensayista, porque a la vez que su afirmación cumple una función crítica (cuestiona las certidumbres que se impusieron como evidencias, inquieta la cristalización de las experiencias estéticas en valores culturales), por esa misma afirmación de lo incierto se establecen las condiciones para el goce literario y para el ejercicio de una inusual forma de la inteligencia, la que consiste en la capacidad de formular un problema como tal, sin dar por presupuesta su resolución, extremando su potencia problematizante. ${ }^{29}$

Isso é precisamente o que ocorre no ensaio sobre Francesca: no início, Borges propõe "atenuar" a discrepância percebida no episódio do poema; entretanto, ao final do ensaio, a discrepância se tornou um "paradoxo insolúvel”. Isto é, ele não quer apenas apresentar uma conclusão que resolva o problema, mas quer sustentar e extremar, tanto quanto possível, a tensão presente no problema.

Entretanto uma observação mais detida do modo como Borges constrói algumas dessas conjeturas pode ser relevante para perceber certos procedimentos nos Ensayos. Ao chegar à quarta conjetura, Borges desenvolve o que ele chama de uma "discussão preliminar", que conduz ao intrincado desfecho de seu ensaio. À pergunta implícita - por que Dante condenou Francesca ao Inferno, se sente tamanha compaixão por ela? -, Borges responde que a atitude de Dante está além da lógica e que, por isso, o problema é um "paradoxo insolúvel": O poeta compreende a personagem, mas não a perdoa. De fato, é isso mesmo o que se verifica: a compaixão de Dante revela, de certo modo, uma compreensão do pecado

28 "A quarta conjetura, como vemos, não deslinda o problema. Limita-se a formulá-lo, de maneira enérgica. As outras conjeturas eram lógicas; esta, que não o é, parece-me ser a verdadeira." (BORGES, 2011, p. 37).

29 "A incerteza é ambiguidade, mas irredutível: ambiguidade que não quer ser reduzida, tensão que não quer ser apaziguada. Por isso, a incerteza é um valor para a ética borgeana, para a ética do ensaísta, porque ao mesmo tempo que sua afirmação cumpre uma função crítica (questiona as certezas que se impuseram como evidências, inquieta a cristalização das experiências estéticas em valores culturais), por essa mesma afirmação do incerto se estabelecem as condições para o prazer literário e para o exercício de uma inusual forma da inteligência, a qual consiste na capacidade de formular um problema como tal, sem dar por pressuposta sua resolução, extremando sua potência problematizante." 
de Francesca; entretanto, se ela está no Inferno, é porque "ele não a perdoa”. Entretanto, uma leitura atenta da Commedia detecta na base da formulação de Borges (1998a, pp. 116-117) uma flagrante contradição com o pensamento dantesco:

Dante comprende y no perdona; tal es la paradoja insoluble. Yo tengo para mí que la resolvió más allá de la lógica. Sintió (no comprendió) que los actos del hombre son necessários y que asimismo es necesaria la eternidad, de bienaventuranza o de perdición, que estos le acarrean..$^{30}$

Nada é mais alheio à Commedia do que a ideia de que os atos humanos são necessários: se o Inferno, o Purgatório e o Paraíso existem, é porque os atos humanos não são necessários, e cabe ao homem escolher como agir. Curiosamente, Borges (1998a, p. 116) cita o momento do poema em que tal concepção é plenamente desenvolvida:

Dante refiere con tan delicada piedad la culpa de Francesca que todos la sentimos inevitable. Así también hubo de sentirla el poeta, a despecho del teólogo que argumentó en el Purgatorio (XVI, 70) que si los actos dependieran del influjo estelar, quedaría anulado nuestro albedrío y sería una injusticia premiar el bien y castigar el mal..$^{31}$

O trecho do Purgatorio é citado quase como um momento casual do poema: Dante encontra mais uma alma (dentre as tantas que encontra em sua viagem), e esta alma afirma a existência do livre-arbítrio, sem maiores consequências. Entretanto, o que Borges não diz é que esse canto está no centro do poema, tanto numericamente como no seu plano ético. De fato, nos cantos XVI, XVII e XVIII do Purgatorio ocorre uma ampla exposição acerca do amor (enquanto disposição da alma humana) e do livre-arbítrio, a qual fundamenta a estrutura moral não só desse cântico, mas também do poema como um todo. Dessa exposição, depreende-se que o amor está na base de todos os atos humanos - o que significa, portanto, que o amor está na origem também dos maus atos do homem. Por isso, cabe ao livre-arbítrio regular a qualidade do amor,

\footnotetext{
30 "Dante compreende e não perdoa; eis o paradoxo insolúvel. Tenho para mim que a questão foi resolvida para além da lógica. Ele sentiu (não compreendeu) que os atos do homem são necessários e que também é necessária a eternidade, de bem-aventurança ou perdição, que esses atos acarretam para quem os comete.” (BORGES, 2011, p. 37).

31 "Dante relata com tão delicada piedade a culpa de Francesca que todos nós a sentimos como inevitável. Assim também deve tê-la sentido o poeta, a despeito do teólogo que argumentou no Purgatorio (XVI, 70) que, se os atos dependessem do influxo estelar, estaria anulado o nosso arbítrio e seria uma injustiça premiar o bem e castigar o mal."
} 
conduzindo-o a bons atos - e isso não foi o que Francesca fez. Dentro desse plano, a condenação dela, por mais que desperte a compaixão do personagem Dante e do leitor, resulta plenamente justificada. Mas Borges, ao descontextualizar um elemento do poema, apropria-se desse elemento:

\begin{abstract}
Ahora bien, la interpretación psicológica que presenta Borges hace caso omiso (por medio de una frase parentética que elimina toda posibilidad de discusión) de la conexión entre la pasión amorosa y el libre albedrío desarrollada por Dante en los cantos centrales del Purgatorio. Para Dante, el mérito de la voluntad que actúa en conformidad con la razón ("intelletto") reside en su absoluto control del apetito sensual [...]. Borges modifica de este modo el significado profundo del mencionado paso, ya que le atribuye a Dante una concepción determinista del actuar humano contraria a la doctrina del libre albedrío mantenida en la Comedia. (NÚÑES FARACO, 2015, p. 430)32
\end{abstract}

Borges dá a impressão de estar simplesmente comentando o poema; entretanto, ele está se apropriando de um elemento, dominando, de maneira muito velada, o rumo que tal elemento tomará: ao dizer que Dante resolveu o problema "para além da lógica", ele se autoriza a conduzir à conclusão que ele mesmo quer que seja a verdadeira, a despeito de tudo quanto esteja exposto no Purgatorio. Logo, o "além da lógica" se torna o seu pretexto, e ele assume a responsabilidade pelo "paradoxo insolúvel" que é a conclusão. Parece não restar ao leitor senão aceitar que a força do episódio está justamente nesse paradoxo não resolvido - e é muito atraente a ideia de que a força poética de um dos episódios mais admirados do poema esteja na sua transposição dos limites da lógica. Isso revela o domínio de Borges sobre a interpretação do poema e os rumos que ela pode tomar: nessa leitura, nada é fortuito.

O ensaio de Francesca manifesta, ainda, outros pontos interessantes. Ao descrever os possíveis modos de resolver a "discrepância", o autor caracteriza a terceira conjectura como "técnica”:

La tercera, como la primera, es de índole técnica. Dante, en el decurso de la Comedia, tuvo que anticipar las inescrutables decisiones de Dios. Sin otra luz

32 "A interpretação psicológica que Borges apresenta ignora (por meio de uma frase parentética que elimina toda possibilidade de discussão) a conexão entre a paixão amorosa e o livre-arbítrio, desenvolvida por Dante nos cantos centrais do Purgatório. Para Dante, o mérito da vontade que atua em conformidade com a razão reside em seu absoluto controle do apetite sensual [...]. Borges modifica desse modo o significado profundo do mencionado trecho, já que atribui a Dante uma concepção determinista da atuação humana, contrária à doutrina do livre-arbítrio mantida na Comédia." 
que la de su mente falible, se lanzó a adivinar algunos dictámenes del Juicio Universal. [...]

Para disimular esa operación, definió a Dios, en el Infierno, por su justicia ("Giustizia mosse il mio alto fattore") y guardó para sí los atributos de la comprensión y de la piedad. (BORGES, 1998, pp. 115-116)33

Das três primeiras conjeturas, essa é a única que Borges não descarta explicitamente. Entretanto, quando o autor diz, a respeito da quarta conjetura: "Las otras conjecturas eran lógicas; esta, que no lo es, me parece verdadera" (BORGES, 1998a, p. 117), ${ }^{34}$ ele afirma a falsidade também da terceira. Isso suscita uma questão interessante na reflexão borgeana. Segundo a terceira conjectura, Dante, ao criar o mundo além-morte, teve também de criar o julgamento divino; para dissimular isso, foi mister diferenciá-lo de seu próprio julgamento e ter como critério uma justiça suprema, para além da sua compaixão. Caso contrário, ele acabaria criando um Deus falso, apenas refletindo o seu sentimento pessoal, que, contudo, é falível. Por isso, Borges diz que essa hipótese é de ordem técnica (situando-se, portanto, não no plano ficcional, mas no plano "real"): trata-se do procedimento ao qual Dante teve de recorrer para construir o mundo de seu poema.

Essa é uma questão também enunciada em "La divina comedia": "Si Dante hubiera coincidido siempre con el Dios que imagina, se vería que es un Dios falso, simplemente una réplica de Dante" (BORGES, 1993, p. 26).35 Mas quando, na conferência, ele descreve a atitude que Dante teve de assumir na composição de seu poema, distingue, ao menos implicitamente, dois planos: a ficção e a "realidade"; e é neste último plano que o poeta é obrigado a operar uma aproximação do julgamento divino. A transferência dessa operação de Dante para o plano da ficção cria a necessidade de um "pacto de leitura”, pois, para entrar verdadeiramente no mundo da Commedia, devemos considerar que estamos lendo a sentença divina, cujos julgamentos particulares podem ou não coincidir

33 "A terceira, como a primeira, é de natureza técnica. Dante, no decurso da Comédia, teve de antecipar as inescrutáveis decisões de Deus. Sem outra luz que a de sua mente falível, lançou-se a adivinhar algumas sentenças do Juízo Universal. /Para dissimular essa opinião, definiu Deus, no Inferno, pela sua justiça ('Giustizia mosse il mio alto fattore') e reservou para si os atributos da compreensão e da piedade." Tradução do citado verso de Inferno III 4 (ALIGHIERI, 1946): "Moveu Justiça o Autor meu sempiterno".

34 "As outras conjeturas eram lógicas; esta, que não o é, parece-me ser a verdadeira." (BORGES, 2011, p. 37).

35 "Se Dante coincidisse sempre com o Deus que imagina, perceber-se-ia que é um Deus falso, simplesmente uma réplica de Dante." 
com o sentimento do personagem Dante. Nesse caso, Francesca e Paolo não podiam não ser condenados - não obstante toda a compaixão que despertam no protagonista:

Se ha dicho que Dante es cruel con Francesca, al condenarla. Pero esto es ignorar al Tercer Personaje. El dictamen de Dios no siempre coincide con el sentimiento de Dante. [...] Dante no segoza con el dolor. Sabeque hay pecados imperdonables, capitales. Para cada uno elige una persona que ha cometido ese pecado, pero que en todo lo demás puede ser admirable o adorable. Francesca y Paolo sólo son lujuriosos. No tienen otro pecado, pero uno basta para condenarlos..$^{36}$

Nessa perspectiva de separação (dentro de um poema escrito em primeira pessoa) entre autor e personagem, não há discrepância no episódio de Francesca, pois, no plano ficcional, sua condenação, da qual o protagonista se compadece, foi decidida pela justiça divina; apenas no plano da "realidade" é uma decisão de Dante, na medida em que ele tenta se aproximar do que seria o julgamento divino.

Entretanto, o que interessa é a ficção, não a realidade - isso é o que Borges afirma no ensaio sobre o famoso verso de Ugolino. Seu tom polêmico já se manifesta no título: "El falso problema de Ugolino" "falso" porque não atenta para a diferença entre arte e realidade: "No he leído (nadie ha leído) todos los comentarios dantescos, pero sospecho que, en el caso del famoso verso 75 del canto penúltimo del Infierno, han creado un problema que parte de una confusión entre el arte y la realidad" (BORGES, 1998a, p. 101).37 Basta dizer que, para o autor, não importa o que tenha feito o homem histórico Ugolino della Gherardesca, mas sim o eterno personagem da Commedia: "El problema histórico de si Ugolino della Gherardesca ejerció en los primeros días de febrero de 1289 el canibalismo es, evidentemente, insoluble. El problema estético o literario es de muy otra índole" (BORGES, 1998, p. 103)..$^{3}$ Entretanto, o

36 "Disseram que Dante é cruel com Francesca, ao condená-la. Mas isso é ignorar o Terceiro Personagem. A sentença de Deus não coincide sempre com o sentimento de Dante. [...] Dante não se compraz com a dor. Sabe que há pecados imperdoáveis, capitais. Para cada um escolhe uma pessoa que o cometeu, mas que em tudo o mais pode ser admirável ou encantadora. Francesca e Paolo são luxuriosos. Não têm outro pecado, mas um basta para condená-los."

37 "Não li (ninguém leu) todos os comentários dantescos, mas tenho a impressão de que, no caso do famoso verso 75 do penúltimo canto do Inferno, eles criaram um problema que parte de uma confusão entre a arte e a realidade." (BORGES, 2011, p. 23).

38 "O problema histórico de saber se nos primeiros dias de fevereiro de 1289 Ugolino della Gherardesca praticou o canibalismo é, evidentemente, insolúvel. O problema estético ou literário é de índole completamente diferente." (BORGES, 2011, p. 25). 
famoso verso ("Poscia, più che 'l dolor, poté 'l digiuno" [Inferno, XXXIII, p. 75]) permite mais de uma possibilidade de interpretação39 (o que se projeta mais uma vez na questão da multiplicidade de sentidos do poema), as quais podem conviver sem prejuízo para a leitura do poema, pois trata-se aqui do tempo da arte, que não só permite a ambiguidade, mas se nutre dela, em oposição à realidade, que não a admite:

En el tiempo real, en la historia, cada vez que un hombre se enfrenta con diversas alternativas opta por una y elimina e pierde las otras; no así en el ambiguo tiempo del arte, que se parece al de la esperanza y al del olvido. Hamlet, en ese tiempo, es cuerdo y es loco. En la tiniebla de su Torre del Hambre, Ugolino devora y no devora los amados cadáveres, y esa ondulante imprecisión, esa incertidumbre, es la extraña materia de que está hecho. Así, con dos posibles agonías, lo soñó Dante y así lo soñarán las generaciones. (BORGES, 1998, pp. $\left.105^{-106}\right)^{4^{\circ}}$

Nesse ensaio, Borges propõe uma interpretação do texto por si mesmo e conclui que existe na cena a convivência de mais de uma possibilidade de leitura; isso significa que a ambiguidade é aqui deliberada. Ao dizer "Reconsideremos la escena" [reconsideremos a cena], Borges (1998a,

39 O que, para o autor, aponta para o valor altamente sugestivo do verso de Dante: “¿Quiso Dante que pensáramos que Ugolino (el Ugolino del Infierno, no el de la historia) comió la carne de sus hijos? Yo arriesgaría la respuesta: Dante no ha querido que lo pensemos, pero sí que lo sospechemos. La incertidumbre es parte de su designio" [Dante quis que pensássemos que Ugolino (o Ugolino do Inferno, não o da história) comeu a carne de seus filhos? Eu arriscaria a resposta: Dante não quis que o pensássemos, mas sim que suspeitássemos que isso acontecera. A incerteza é parte de seu desígnio.] (BORGES, 1998a, pp. 103-104). Segundo Italo Calvino, a sugestão é especialmente cara a Borges e à sua arte de escrever brevemente: "Borges è un maestro dello scrivere breve. Egli riesce a condensare in testi sempre di pochissime pagine una ricchezza straordinaria di suggestioni poetiche e di pensiero: fatti narrati o suggeriti, aperture vertiginose sull'infinito, e idee, idee, idee" [Borges é um mestre do escrever breve. Ele consegue condensar em textos de sempre pouquíssimas páginas uma riqueza extraordinária de sugestões poética e de pensamento: fatos narrados ou sugeridos, aberturas vertiginosas sobre o infinito, e ideias, ideias, ideias.] (CALVINO, 2001, p. 1.294).

40 Esse talvez seja o maior exemplo, nos Ensayos dantescos, da persistência deliberada na incerteza; e talvez seja a solução mais aclamada de todo o livro. Entretanto, pese aos estudiosos de Borges, essa ainda é a sua formulação mais próxima das leituras críticas, justamente porque toma o texto por si. Não se trata de afirmação revolucionária, mas de uma ideia já presente - ainda que com pouca frequência - entre os comentadores da Commedia, como Luigi Pietrobono, citado em nota pelo próprio Borges (1998a, p. 104) - o que não apraz aos estudiosos dos Ensayos dantescos recordar -. Aqui, a força - e a novidade - não está tanto na ideia de uma ambiguidade deliberada por parte de Dante, mas na formulação extrema de Borges: "Ugolino devora y no devora los amados cadáveres” [Ugolino devora e não devora os cadáveres amados.] (p. 106). 
p. 101) de fato reconsidera a cena, e trata de diversos elementos que se projetam no vislumbre do canibalismo:

Ugolino roe el cráneo del arzobispo; Ugolino sueña con perros de colmillos agudos que rasgan los flancos del lobo [...]. Ugolino, movido por el dolor, se muerde las manos: Ugolino oye que los hijos le ofrecen inverosímilmente su carne; Ugolino, pronunciando el ambiguo verso, torna a roer el cráneo del arzobispo. Tales actos sugieren o simbolizan el hecho atroz. Cumplen una doble función: los creemos parte del relato y son profecías. (BORGES, 1998a, p. 104) ${ }^{41}$

Toda a discussão se desenvolve no plano da ficção e considera aquilo que esta sugere. Até quando diz que Dante quis que pensássemos no possível canibalismo de Ugolino, Borges não sai do plano da "textura verbal”, pois não se trata aqui de uma transferência da ficção para a realidade: dizer que Dante quis que pensássemos é dizer que o texto quer ser lido dessa forma; trata-se, portanto, de uma intenção da própria ficção.

O autor, contudo, não segue esse mesmo procedimento em todos os Ensayos dantescos. No ensaio sobre Ulisses, ele propõe justamente o contrário: enquanto muitos estudiosos traçam um paralelo entre a viagem de Ulisses e a viagem de Dante, Borges (1998, p. 110) propõe um paralelo entre Ulisses e o Dante histórico - realizando, portanto, uma sobreposição entre ficção e realidade:

La acción de Ulises es indudablemente el viaje de Ulises, porque Ulises no es otra cosa que el sujeto de quien se predica esa acción, pero la acción o empresa de Dante no es el viaje de Dante, sino la ejecución de su libro. El hecho es obvio, pero se propende a olvidarlo, porque la Comedia está redactada en primera persona, y el hombre que murió ha sido oscurecido por el protagonista inmortal. ${ }^{42}$

41 "Ugolino rói o crânio do arcebispo; Ugolino sonha com cachorros com dentes afiados que rasgam os lados do lobo. [...] Ugolino, movido pela dor, morde suas mãos: Ugolino ouve que seus filhos lhe oferecem inverossimilmente sua carne; Ugolino, pronunciando o ambíguo verso, torna a roer o crânio do arcebispo. Tais atos sugerem ou simbolizam o ato atroz. Cumprem uma dupla função: não os tomamos como parte do relato e são profecias." 42 "A ação de Ulisses é indubitavelmente a viagem de Ulisses, pois Ulisses não é mais que o sujeito de quem se apregoa essa ação, mas a ação ou empresa de Dante não é a viagem de Dante, e sim a execução de seu livro. O fato é óbvio, mas existe uma tendência a deixá-lo de lado, porque a Comédia é redigida na primeira pessoa e o homem que morreu ficou encoberto pelo protagonista imortal." (BORGES, 2011, pp. 30-31). 
E aqui o interessante é que, antes de propor abertamente a sua leitura, Borges apresenta diversos elementos textuais que corroboram justamente a ideia de um paralelo entre Ulisses e o protagonista do poema. De fato, assim se inicia o ensaio: "Mi propósito es reconsiderar, a la luz de otros pasajes de la Comedia, el enigmático relato que Dante pone en boca de Ulises" (BORGES, 1998a, p. 107).43 Cria-se a impressão de que Borges procederá tal como em "El falso problema de Ugolino", propondo uma leitura do episódio com base na "textura verbal". Até certo ponto, é isso o que ele faz; seguindo a letra do texto, o ensaio chega a uma interpretação do poema que coincide com o juízo de muitos comentadores: há um paralelo entre Ulisses e o protagonista do poema. Entretanto, não é essa a verdadeira interpretação de Borges; por isso, o ensaio abre mão de uma interpretação do texto pelo texto (isto é, abre mão do propósito inicialmente apresentado), em favor de uma sobreposição entre a ficção do poema (o personagem Ulisses) e a realidade (o homem histórico Dante).

Tal sobreposição ganha sua maior expressão nos ensaios sobre Beatriz: neles, o autor não hesita em realizar interpretações da ficção totalmente fundadas no plano real. Só assim se explica toda a dimensão trágica que ele vê no último sorriso da personagem. E é especialmente característica desses ensaios a concentração não só no que seria o plano real, mas, mais do que isso, na inacessível subjetividade de Dante. Nos dois últimos ensaios de seu volume, Borges (1998a, p. 144) se aplica em descrever os possíveis sentimentos de Dante ao compor determinados momentos do poema, chegando a criar mesmo novas ficções sobre o poeta: "Dante, muerta Beatriz, perdida para siempre Beatriz, jugó con la ficción de encontrarla para mitigar su tristeza; yo tengo para mí que edificó la triple arquitectura de su poema para intercalar ese encuentro". ${ }^{44}$ $\mathrm{O}$ mesmo ocorre quando o autor afirma que foi com inveja que o poeta escreveu seu encontro com Francesca:

Infinitamente existió Beatriz para Dante. Dante, muy poco, tal vez nada, para Beatriz; todos nosotros propendemos por piedad, por veneración, a olvidar esa lastimosa discordia inolvidable para Dante. Leo y releo los azares de su ilusorio encuentro y pienso en dos amantes que el Alighieri soñó en el huracán del segundo círculo y que son emblemas oscuros, aunque él no lo entendiera

43 "Meu objetivo é reconsiderar, à luz de outros trechos da Comédia, o enigmático relato que Dante põe na boca de Ulisses." (BORGES, 2011, p. 28).

44 "Dante, morta Beatriz, perdida para sempre Beatriz, brincou com a ficção de encontrá-la, para assim mitigar sua tristeza; tenho para mim que ele edificou a tripla arquitetura de seu poema para intercalar esse encontro." (BORGES, 2011, p. 55). 
o no lo quisiera, de esa dicha que no logró. Pienso en Francesca y en Paolo, unidos para siempre en su Infierno. ("Questi, che mai da me non fia diviso...") Con espantoso amor, con ansiedad, con admiración, con envidia. (BORGES, 1998a, p. 145 $)^{45}$

Como aponta Giordano (2005c, p. 64), trata-se de uma leitura imaginativa por parte de Borges: "Borges presiente la sombra de Dante proyectándose discretamente sobre sus criaturas; imagina a Dante, su pasión por una mujer y por las letras, en las faltas de motivación o en las discordias que dan a su invención un aura incierta”. ${ }^{6}$ Em casos como esse, as fronteiras do ensaio se tornam flutuantes:

\begin{abstract}
De ahí la sensación de incertidumbre que experimentamos al leer un ensayo de Borges: no sabemos con precisión si se trata de un relato fantástico o de una exposición crítica sobre un asunto determinado. En este sentido, Borges desdibuja los límites reconocibles del género ensayístico, dotándolo de una carga ficcional que lo aproxima peligrosamente a sus ficciones o cuentos. Se rompe así la rigidez y la arbitrariedad del discurso logocéntrico, ya que los ensayos de Borges y la concepción literaria que aportan tienen un propósito desrealizador. (ARDAVÍN, 1996, p. 81) ${ }^{47}$
\end{abstract}

45 "Infinitamente existiu Beatriz para Dante. Dante, muito pouco, talvez nada para Beatriz; todos nós tendemos por piedade, por veneração, a esquecer essa lastimável discórdia inesquecível para Dante. Leio e releio os azares de seu ilusório encontro e penso em dois amantes sonhados por Alighieri no furacão do segundo círculo e que são símbolos obscuros, embora ele não o entendesse, ou não o desejasse, dessa felicidade que não obteve. Penso em Francesca e em Paolo, unidos para sempre em seu Inferno ('Questi, che mai da me non fia diviso...'). Com tremendo amor, com ansiedade, com admiração, com inveja Dante terá composto esse verso." (BORGES, 2011, p. 56). Tradução do citado verso de Inferno V 135 (ALIGHIERI, 1946): "Este, que mais de mim não se separa...."

46 "Borges pressente a sombra de Dante projetando-se discretamente sobre suas criaturas; imagina Dante, sua paixão por uma mulher e pelas letras, nas faltas de motivação ou nas discórdias que dão à sua invenção uma aura incerta."

47 "Daí a sensação de incerteza que experimentamos ao ler um ensaio de Borges: não sabemos com precisão se se trata de um relato fantástico ou de uma exposição crítica sobre um determinado assunto. Nesse sentido, Borges desenha os limites reconhecíveis do gênero ensaístico, dotando-o de uma carga ficcional que o aproxima perigosamente de suas ficções ou contos. Rompe-se, assim, a rigidez e a arbitrariedade do discurso logocêntrico, já que os ensaios de Borges e a concepção literária que fornecem têm um propósito desrealizador." E, mais adiante: "La subordinación de la obra artística a la categoría genérica tiene consecuencias devastadoras en el orden creativo, ya que no deja espacio a la necesaria espontaneidad que ha de caracterizar a toda auténtica creación estética, destinada fundamentalmente a producir emoción, belleza, regocijo. [...] Aceptando plenamente este precepto de la estética crociana, Borges recusa la noción tradicional de género literario, invalidando sus estructuras y creando una especie de forma ensayística alterna, donde el 'élan vital' bergsoniano produce un ámbito creativo inédito, en el que lo ficticio y lo real se entremezclan en una intrincada urdimbre de interrelaciones. Borges 
E, para voltar mais uma vez ao problema de Francesca, cumpre dizer que, considerando-se tão-somente o plano ficcional, o episódio não apresenta discrepância: Deus condena Francesca e Paolo; o personagem Dante se compadece deles. Essa não é, contudo, a leitura proposta pelo ensaio "El verdugo piadoso": quando Borges (1998a, p. 113) diz "Dante [...] pone a Francesca en el Infierno y oye con infinita compasión la historia de su culpa" ${ }^{48}$ ele cria uma identificação total entre o autor, que na realidade colocou a personagem no Inferno, e o protagonista, que na ficção ouve com compaixão a sua história. Aqui, não há mais paralelo ou sobreposição, como no caso de Ulisses, mas a mesma "confusão entre arte e realidade" atribuída, no ensaio sobre Ugolino, aos comentadores dantescos.

Em tal complexo, os Nueve ensayos dantescos se revelam uma trama não só de diferentes temas, mas também de diferentes procedimentos de aproximação do poema de Dante. É como se o mesmo valor que Borges atribui ao detalhe, individualizando-o, fosse traduzido na individualização de cada um de seus ensaios: para cada novo tema, um novo tratamento. Tem-se aqui, mais uma vez, um efeito da oposição de Borges às leituras totalizantes: assim como o autor não quer tomar o texto clássico em sua leitura totalizante, ele também não quer apresentar seus ensaios como um todo completamente coerente.

Sus lecturas sonvariables, móviles, y no corresponden a ningún ideal decoherencia absoluta ni del texto literario, ni de su propia labor ensayística. Esto convierte a Borges en un lector y un crítico particular, cuya obra no ha de ser comprendida en términos de unidad. Cada uno de sus textos hace uso de diversas herramientas para poder realizar sus interpretaciones. (VALENCIA, 2015, p. 940) ${ }^{49}$

\footnotetext{
niega la esencia arquetípica del género literario y deja su delimitación al libre albedrío del autor" [A subordinação da obra artística à categoria de gênero tem consequências devastadoras na ordem criativa, já que não deixa espaço à necessária espontaneidade que deve caracterizar qualquer criação estética autêntica, destinada fundamentalmente a produzir emoção, beleza, regozijo. [...] Aceitando plenamente esse preceito da estética crociana, Borges recusa a noção tradicional de gênero literário, invalidando suas estruturas e criando uma espécie de forma ensaística alternativa, em que o "élan vital" bergsoniano produz um âmbito criativo inédito, no qual o fictício e o real se envolvem em uma intrincada trama de inter-relações. Borges nega a essência arquetípica do gênero literário e deixa sua delimitação ao livre-arbítrio do autor.] (ARDAVÍN, 1996, p. 82).

48 "Dante [...] põe Francesca no Inferno e ouve com infinita compaixão a história de sua culpa" (BORGES, 2011, p. 34).

49 "Suas leituras são variáveis, móveis, e não correspondem a nenhum ideal de coerência absoluta do texto literário, nem de seu próprio trabalho ensaístico. Isso faz de Borges um leitor e um crítico particular, cuja obra não deve ser compreendida em termos de unidade. Cada um de seus textos faz uso de diversas ferramentas para poder realizar suas interpretações."
} 
As contradições deixam de ser um problema, pois, ainda que não se possa falar de unidade, os Ensayos dantescos têm como fundo comum a intenção de destacar fenômenos estéticos, em seus efeitos sobre a emoção do leitor. Esta pode ser caracterizada como a postura de um leitor hedônico, explicitamente assumida por Borges (1993, p. 11):

\begin{abstract}
Creo, sin embargo, en la conveniencia de ese concepto ingenuo, ese concepto de que estamos leyendo un relato verídico. Sirve para que nos dejemos llevar por la lectura. De mí sé que soy un lector hedónico; nunca he leído un libro porque fuera antiguo. He leído libros por la emoción estética que me deparan y he postergado los comentarios y las críticas. Cuando leí por primera vez la Comedia, me dejé llevar por la lectura. He leído la Comedia como he leído otros libros menos famosos..$^{50}$
\end{abstract}

Essa última afirmação, caracterizando sua atitude diante da Commedia, pode traduzir, em perspectiva mais ampla, sua atitude diante do texto clássico em geral. Borges não se subordina ao valor preestabelecido de "clássico", mas, partindo do pressuposto de que a Commedia é um livro como outro qualquer, deixa-se cativar pelo seu poder de criar emoção estética.

Ao assumir tal postura, ele problematiza o valor de clássico, enquanto institucionalização que predetermina o texto e impõe certa leitura. Para Borges não há leitura imposta; suas interpretações vão no sentido de desestabilizar qualquer tipo de imposição a respeito da obra literária, sujeita, do contrário, a sofrer desgaste em nome de sua condição canônica:

En Borges, la noción de lectura implica la presencia de múltiples elementos y relaciones que modifican el texto y lo hacen inagotable. Por ello, la idea de un texto completamente coherente se ve cuestionada y deja de ser un ideal que rige la lectura. Tal postura implica una mayor libertad a la hora de leer e interpretar todos los textos, incluso aquellos que se han convertido en clásicos. (VALENCIA, 2015, p. 937) $)^{51}$

50 "Acredito, contudo, na conveniência dessa concepção ingênua, dessa concepção de que estamos lendo um relato verídico. Serve para que nos deixemos levar pela leitura. De mim, sei que sou um leitor hedônico; nunca li um livro por ser antigo. Li livros pela emoção estética que me proporcionam e adiei os comentários e as críticas. Quando li pela primeira vez a Comédia, deixei-me levar pela leitura. Li a Comédia como li outros livros menos famosos."

51 "Em Borges, a noção de leitura implica a presença de múltiplos elementos e relações que modificam o texto e o tornam inesgotável. Por isso, a ideia de um texto completamente coerente se vê questionada e deixa de ser um ideal que rege a leitura. Tal postura implica uma maior liberdade na hora de ler e interpretar todos os textos, inclusive aqueles que se tornaram clássicos." 
No caso dos Ensayos dantescos, a maior liberdade do autor ao lidar com o texto clássico traça um trabalho de "recriação" do poema dantesco - "recriação" para a sensibilidade do leitor. Se há algo que os Ensayos evidenciam é que, em Borges, a leitura não é um processo passivo, mas um constante trabalho da imaginação, mediante o qual o autor se apropria do texto de Dante, acrescentando-lhe algo de seu. É, como disse Calvino (2001, p. 1.300), uma participação congenial que faz frutificar a herança dantesca: "Lo studio assiduo e appassionato del testo capitale della nostra letteratura, la partecipazione congeniale con cui egli ha messo a frutto l'eredità dantesca nella meditazione critica e nell'originalità dell'opera creativa".52 Por outro lado, cumpre esclarecer, tal apropriação não redunda em paródia, mas sim em assimilação crítica:

Los ensayos, relatos y poemas con temas dantescos escritos por Borges a lo largo de su vida constituyen un buen ejemplo de aquella poética de la irreverencia promovida con tanto fervor en la conferencia de 1951. Lejos de afirmar un tratamiento paródico de la Comedia, dichas obras demuestran que el concepto de "irreverencia" - afín a su gusto por lo heterodoxo y lo herético - no implica la burla o el sarcasmo sino más bien una asimilación crítica, una postura intelectual que imprime el sello personal del autor frente a la tradición. (NÚÑES FARACO, 2015, p. 431) 53

É nesse sentido que não se pode falar de "leitura inocente": Borges, em suas leituras dantescas, não só define certa postura diante da tradição, mas também imprime, com consciência, algo de seu nessa mesma tradição. Trata-se de uma leitura não isenta de malícia, de uma apropriação, de certo modo "contra-canônica", que não poupa meios para realizar a sua própria recriação - ainda que tais meios impliquem contradições:

Me interesa enfatizar que la lectura borgeana es "contra-canónica" en el sentido de que no se preocupa por ver estos textos como unidades coherentes y predeterminadas y trata, más bien, de cuestionar esta mirada preestablecida sobre los clásicos. Sus ensayos proponen apropiaciones personales, fragmentarias e irreverentes de diversos aspectos de cada obra. Es también una

52 "O estudo assíduo e apaixonado do texto capital da nossa literatura, a participação congenial com a qual ele faz frutificar a herança dantesca na reflexão crítica e na originalidade da obra criativa."

53 "Os ensaios, relatos e poemas com temas dantescos escritos por Borges ao longo de sua via constituem um bom exemplo daquela poética da irreverência promovida com tano fervor na conferência de 1951. Longe de afirmar um tratamento paródico da Comédia, ditas obras demonstram que o conceito de 'irreverência' - análogo a seu gosto pelo heterodoxo e pelo herético - não implica burla ou sarcasmo, mas, melhor, uma assimilação crítica, uma postura intelectual que imprime a marca pessoal do autor diante da tradição." 
lectura que al realizar ciertos énfasis y al dar preeminencia a algunas metáforas, implica interpretaciones sesgadas, silencios estratégicos y contradicciones. (VALENCIA, 2015, pp. 936-937) ${ }^{54}$

Nessa perspectiva, não cabe criar uma oposição muito pronunciada entre Borges e a crítica literária. Os comentários críticos certamente não são reverenciados, mas tampouco são indistintamente descartados: são mais um aparato como tantos outros, que ele não hesitará em ignorar caso não sirvam a seus fins.

A complexa textura dos Nueve ensayos dantescos, feita de diferentes expedientes e posicionamentos, descreve uma leitura deliberadamente parcial da Commedia. Neles, nenhuma citação, nenhuma ênfase e nenhum silêncio são casuais: tudo está inserido em um jogo de formulações e fusões entre realidade e ficção, cujo resultado é não raras vezes desorientar o leitor. Borges certamente não é inocente, mesmo onde mais aparente sê-lo: na verdade, é onde a máscara da inocência mais parece agir que seu trabalho de apropriação se realiza de modo mais completo. Talvez sua leitura só possa ser considerada inocente no sentido que lhe atribuiu Alberto Giordano (2005c, pp. 64-65), no seguinte trecho: "El lector inocente es, según vimos, un lector impertinente, un lector lo suficientemente audaz como para reconocer y no sólo reconocer sino también apreciar, las fallas que mantienen vivos los monumentos culturales". ${ }^{55}$ Nesse sentido, e falando agora especificamente na perspectiva dos estudos dantescos, pode-se dizer que os Nueve ensayos dantescos valem sobretudo como provocação, como modo de levar a crítica a revisar suas formulações mais automatizadas, ainda que seja para não concordar com Borges - como sói acontecer: o que importa é que a reflexão crítica sempre permaneça.

54 "Interessa-me enfatizar que a leitura borgeana é contracanônica no sentido de que não se preocupa por tais textos como unidades coerentes e predeterminadas e trata, na verdade, de questionar esse olhar preestabelecido sobre os clássicos. Seus ensaios propõem apropriações pessoais, fragmentárias e irreverentes de diversos aspectos de cada obra. É também uma leitura que, ao realizar certas ênfases e ao dar preeminências a algumas metáforas, envolve interpretações tendenciosas, silêncios estratégicos e contradições."

55 "O leitor inocente é, segundo vimos, um leitor impertinente, um leitor suficientemente audacioso para reconhecer, e não só reconhecer como também apreciar, as falhas que mantêm vivos os monumentos culturais." 


\section{BORGES READER OF DANTE}

Abstract: One of the most commonly emphasized aspects in the Nueve ensayos dantescos is the deviation of a supposed predominant tone in the practice of literary criticism - a deviation that is frequently translated in terms of an opposition between Borges and the Dantesque criticism. Nevertheless, although Borges indeed moves away from the general tone of the Dantesque studies, this polarization, whose terms seem to be inappropriately simplified, runs the risk of remaining on the margins of the real problem present in his readings of the Commedia. Even though Borges' formulations may seem answers of an innocent reader in front of a masterpiece which encompasses infinite complexities, the truth is they conceal a plot of reading strategies - which frequently contradict each other -, that could hardly be characterized as "innocent". The key of Borges's readings, who time and again seeks to find flaws and incoherencies in one of the classics par excellence, can be considered the way the author confronts the "holistic readings" to which the canonical books are constantly submitted. His attitude, therefore, doesn't quit being critical: as Italo Calvino well observed, the Ensayos dantescos are a re-creation of elements of the poem and, thus, indicate Borges's position in front of the tradition. The proposal of this study is, therefore, to recognize, maintaining always a straight contact with Dante's text, the different reading strategies of Borges and its critical implications throughout the Nueve ensayos dantescos.

Keywords: Nueve ensayos dantescos; Jorge Luis Borges; Dante Alighieri.

\section{REFERÊNCIAS}

ALIGHIERI, Dante. A divina comédia. Texto crítico italiano da Società Dantesca Italiana; ilustrado com 136 gravuras por Gustavo Dore; trad. José Pedro Xavier Pinheiro. São Paulo: Edigraf, 1946.

ARCE, Joaquín. Presentación: Borges, lector de la Divina comedia. In: BORGES, Jorge Luis. Nueve ensayos dantescos. Intr. Marcos Ricardo Barnatán. 3. ed. Madrid: Espasa-Calpe, 1998, pp. 75-8o.

ARDAVÍN, Carlos. Hacia una definición borgeana de la literatura: Dante y la Divina Comédia. Chasqui, v. 25, n. 2, 1996, pp. 81-88.

BARNATÁN, Marcos Ricardo. Introducción. In: BORGES, Jorge Luis. Nueve ensayos dantescos. Intr. Marcos Ricardo Barnatán. 3. ed. Madrid: Espasa-Calpe, 1998a, pp. 13-73.

BARNATÁN, Marcos Ricardo. Noticia Preliminar. In: BORGES, Jorge Luis. Nueve ensayos dantescos. Intr. Marcos Ricardo Barnatán. 3. ed. Madrid: Espasa-Calpe, 1998b, pp. 9-11.

BORGES, Jorge Luis. La divina comedia. In: Siete noches. Madrid: Fondo de Cultura Económica, 1993, pp. 7-32. (Terra Firme)

BORGES, Jorge Luis. O aleph. 1o. ed. São Paulo: Globo, 1996. 
BORGES, Jorge Luis. Nueve ensayos dantescos. Intr. Marcos Ricardo Barnatán. 3. ed. Madrid: Espasa-Calpe, 1998a.

BORGES, Jorge Luis. Sobre os clássicos. In: Outras inquisições. Obras completas. V. 2. Trad. Sérgio Molina. São Paulo: Globo, 1998b, pp. 167-169.

BORGES, Jorge Luis. O fazedor. São Paulo: Companhia das Letras, 2008.

BORGES, Jorge Luis. Nove ensaios dantescos E a memória de Shakespeare. Trad. Heloisa Jahn. São Paulo: Companhia das Letras, 2011.

CALVINO, Italo. Jorge Luis Borges. In: Narratori, poeti, saggisti. In: Saggi, 1945-1985. Mario Barenghi (Ed.). 3. ed. Milão: Arnoldo Mondadori, 2001, pp. 757-1.465.

DANTE. La commedia, secondo l'antica vulgata. A cura di Giorgio Petrocchi. Milão: Arnoldo Mondadori (Società Dantesca Italiana), 1966-1967.

FRESKO, Susanna. Borges, Dante e l'ambiguo tempo dell'arte. Doctor Virtualis. Rivista online di storia della filosofia medievale, v. III, 2003, pp. 33-44. Disponível em: $<$ http://riviste.unimi.it/index.php/DoctorVirtualis/article/view/39/58>. Acesso em: 3 jun. 2017.

GIORDANO, Alberto. Borges: la ética e la forma del ensayo. In: Modos del ensayo: de Borges a Piglia. Rosario: Beatriz Viterbo, 2005a, pp. 9-26.

GIORDANO, Alberto. Borges: la forma del ensayo. In: Modos del ensayo: de Borges a Piglia. Rosario: Beatriz Viterbo, 2005b, pp. 27-52.

GIORDANO, Alberto. Borges y la ética del lector inocente (Sobre los Nueve ensayos dantescos). In: Modos del ensayo: de Borges a Piglia. Rosario: Beatriz Viterbo, 2005c, pp. 53-67.

LAGORIO, Gina. Borges e Dante. Doctor Virtualis. Rivista online di storia della filosofia medievale, v. III, 2003, pp. 25-32. Disponível em: http://riviste.unimi.it/index.php/ DoctorVirtualis/article/view/38/56. Acesso em: 3 jun. 2017.

MENOCAL, María Rosa. Writing in Dante's Cult of Truth: From Borges to Boccaccio. Durham/Londres: Duke University Press, 1991.

NÚÑES FARACO, Humberto. Dante, precursor de Borges. Neophilologus, 2015, pp. 419132.

SESSA, Lucio. Borges e Dante: una sintonia “sospetta”. In: CERBO, Anna (Org.). Lectura Dantis 2002-2009: omaggio a Vincenzo Placella per i suoi settanta anni. T. II. Napoli: Università degli Studi di Napoli “L’Orientale”, 2011, pp. 731-745.

VALENCIA, Norman. Borges y el texto clásico como institución: lecturas contracanónicas del Quijote y la Commedia. Bulletin of Hispanic Studies, v. 92, n. 8, 2015, pp. 933-947. 